Mycologia, 100(2), 2008, pp. 306-310.

C 2008 by The Mycological Society of America, Lawrence, KS 66044-8897

\title{
Gloiocephala cerkezii, a new species from Croatia
}

\author{
Zdenko Tkalčec \\ Armin Mešić ${ }^{1}$ \\ Laboratory of Biocoenotic Research, Ruđer Bošković \\ Institute, Bijenička cesta 54, HR-10000 Zagreb, \\ Croatia
}

\begin{abstract}
A new species, Gloiocephala cerkezii, is described from Croatia. It is characterized by a pale brown to rusty brown pileus, an elongated central to slightly eccentric stipe, vein-like lamellae, large and elongate spores, subcapitate to capitate cystidia, a gelatinized trama, and the absence of hairs on the pileus and stipe. The description is accompanied by black and white photograph of basidiocarps and line drawings of microscopic elements. G. cerkezii is compared to closely related species, and a dichotomous key to European species of the genus Gloiocephala is provided. A new combination Gloiocephala
\end{abstract} pseudocaricis is made.

Key words: Agaricales, Basidiomycota, dichotomous key, taxonomy

\section{INTRODUCTION}

Ten y ago we started an intensive research of Croatian mycobiota. Initially we made a survey of all species of the order Agaricales s.l. recorded for Croatia until 1999 (Mešić and Tkalčec 2002, Tkalčec and Mešić 2002, Mešić and Tkalčec 2003, Tkalčec and Mešić 2003a, b). No species of Gloiocephala Massee were originally recorded. Subsequently we continued with a fieldwork which resulted in the discovery of many species new to Croatia, as well as a few species new to science. So far we have found four species of Gloiocephala in Croatia, G. caricis (P. Karst.) Bas, G. cornelii (Laessøe et Noordel.) E. Horak and G. menieri (Boud.) Singer, as well as a new species, G. cerkezii, that we describe in this paper.

Significant contributions to knowledge on the genus Gloiocephala was made by Singer (1960, 1976, 1986, 1989). In addition several new species of Gloiocephala have been described (e.g. Noordeloos 1987, Horak and Desjardin 1994, Desjardin et al 1995, Desjardin and Horak 1997, Manimohan and Thomas 1998, Antonín 2003). On the basis of its large spores and absence of long hairs G. cerkezii would be classified in section Gloiocephala, subsection Macro-

Accepted for publication 9 November 2007.

${ }^{1}$ Corresponding author. E-mail: amesic@irb.hr sporae, according to Singer's (1986) classification. Some authors have treated Gloiocephala as a section or subgenus of the genus Marasmius (e.g. Antonín and Noordeloos 1993, Noordeloos 1995, Corner 1996, Bon 1999). Recent molecular analyses on the phylogeny of the Agaricales places Gloiocephala, including its type species G. epiphylla Massee and G. menieri (Boud.) Singer, in the Physalacriaceae (Moncalvo et al 2002, Binder et al 2006, Matheny et al 2007). In these same analyses the type of Marasmius occurs in a separate family, the Marasmiaceae. Hence we choose to describe our new species in Gloiocephala, but this issue requires further research.

\section{MATERIALS AND METHODS}

Our description of Gloiocephala cerkezii is based on nine collections and 105 basidiocarps collected on two localities in northwestern Croatia. All collected material and data are deposited in CNF (Croatian National Fungarium, Zagreb). Basidiocarps were preserved by drying. Microscopic features were observed by a light microscope (bright field) with magnification $<1500 \times$. All drawings were made with the help of a drawing tube. Description of macroscopic characters were based on observations of fresh basidiocarps, whereas description and illustrations of microscopic characters were based on rehydrated dried specimens mounted in $5 \%$ potassium hydroxide $(\mathrm{KOH})$. Some hyaline elements were observed in Congo red ( $1 \%$ water solution) after pretreatment in $5 \% \mathrm{KOH}$. From each collection one mature basidiocarp was chosen and 30 randomly selected spores were measured (including the apiculus). Spore measurements (length, width) are given as: (min.) stat. min. - av. stat. max. (max), where "min." = minimum (lowest measured value), "stat. min." = statistical minimum (arithmetic average minus two times standard deviation), "av." = arithmetic average, "stat. max." = statistical maximum (arithmetic average plus two times standard deviation), "max." = maximum (highest measured value). The range of arithmetic averages (av.) of spore measurements of each particular collection also is given. Standard deviation (SD) of spore length and width is given as: min. av. - max. The length/width ratio of spores is given as the " $Q$ " value (min. - av. - max.), and range of arithmetic averages of " $Q$ " value ( $Q$ av.) of each particular collection also is given.

\section{RESULTS}

Gloiocephala cerkezii Tkalčec et Mešić, sp. nov.

FIGS. 1-2

MYCOBANK MB 511240

Etymology. Dedicated to Mr Milan Čerkez in recog- 


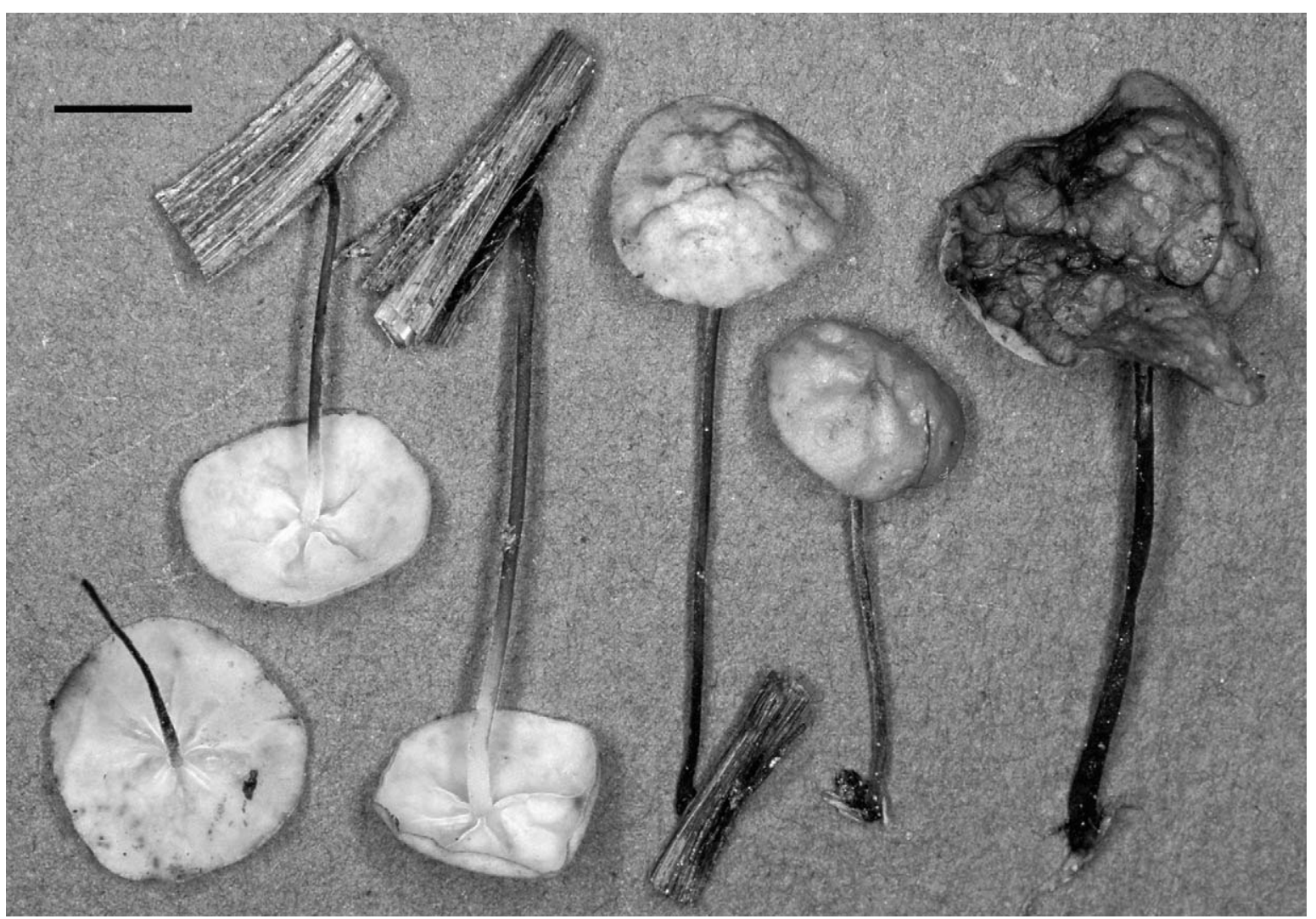

FIG. 1. Basidiocarps of Gloiocephala cerkezii (holotype). Bar $=5 \mathrm{~mm}$.

nition of his great fieldwork contributions to the knowledge of the Croatian mycobiota.

Pileus (3-)5-13(-19) mm latus, convexus, plano-convexus, applanatus vel plano-concavus, rugosus, saepe venosus, opacus, siccus, minute granulato-pubescens sub lente, non hygrophanus, pallide brunneus (raro cremeus) vel ferrugineo brunneus. Lamellae veniformes, irregulares, adnatae vel subdecurrentes, valde distantes, saepe furcatae et intervenosae, rarissime marginem pilei attingentes, hymenium inter lamellis \pm rugosum, albicans vel dilute ochraceum, maculis ferrugineis saepe notatum. Stipes (9)11-25 × $0.2-1 \mathrm{~mm}$, centralis vel excentricus, cylindricus, basi saepe \pm dilatata, insiticius vel subinsiticius, pubescens, siccus, apice plerumque albicans, inferne brunneus, deinde atrofuscus vel niger. Contextus tenuissimus. Odor nullus. Depositum sporarum album.

Sporae $10.5-14.4-21.0 \times 3.1-4.0-5.2 \mu \mathrm{m}, \mathrm{Q}=2.4-3.6-$ 5.3 , anguste fusiformes vel anguste clavatae, hyalinae, tenuitunicatae, non amyloideae. Basidia 27-51 $\times 5-9 \mu \mathrm{m}$, plerumque tetrasporigera. Cystidia hymenialia difformia: alia forma pileocystidiis similis, altera hyphoidea $23-50 \times 2$ $5 \mu \mathrm{m}$. Trama pilealis et hymenophoralis irregularis, gelatinosa, hyphae 1-6 $\mu \mathrm{m}$ latae, tenuitunicatae. Pileipellis hymeniformis, elementa heteromorpha, 10-43 × 3-24 $\mu \mathrm{m}$, hyalina vel brunnea, tenuitunicata vel crassitunicata (ad $3 \mu \mathrm{m})$, pigmentum parietale. Pileocystidia $37-85 \times 5.5-$ $13 \mu \mathrm{m}$, apice $4.5-13 \mu \mathrm{m}$, anguste utriformia, lageniformia, fusiformia, anguste clavata vel subcylindrica, plerumque subcapitata vel capitata, hyalina vel brunnea, plerumque tenuitunicata, abundantia. Stipitipellis cutis est, hyphae 1.5$6 \mu \mathrm{m}$ latae, brunneae. Caulocystidia 21-75 × 6-17 $\mu \mathrm{m}$, apice $4-10.5 \mu \mathrm{m}$, pileocystidiis similia, in basi saepe forte dilatata, hyalina vel brunnea obscura, tenuitunicata vel crassitunicata (ad $2.5 \mu \mathrm{m})$. Fibulae abundantes.

In pratis humidis in partibus emortuis speciei Carex hirta et in pomariis derelictis in ramulis radicum emortuis speciei Prunus domestica. Aestate-autumno.

HOLOTYPUS: CROATIA, Zagreb, Sisak, Dužica, $45^{\circ} 31^{\prime} 54^{\prime \prime} \mathrm{N}, 16^{\circ} 12^{\prime} 35^{\prime \prime} \mathrm{E}, 110 \mathrm{~m}$ s. m., in pratis humidis, in partibus emortuis speciei Carex hirta, 21 Sep 2002, leg. M. Čerkez, in CNF fungario conservatus (1/2768).

Pileus (3-)5-13(-19) mm broad, convex, planoconvex, applanate or plano-concave, often with an irregularly warped edge (down or up), wrinkled, often venose, mat, dry, finely granular-pubescent under hand lens, sometimes with minute dark brown dots (resinous exudates), not hygrophanous, pale brown (rarely cream) to rusty brown, more or less irregularly pigmented. Lamellae vein-like, irregular, adnate to subdecurrent, distant, $\mathrm{L}=(4-) 5-7(-8), 1=$ $0(-1)$, often furcate or intervenose, very rarely reaching the margin of pileus, often not exceeding half the radius, hymenial surface between the lamellae often more or less wrinkled, hymenium 


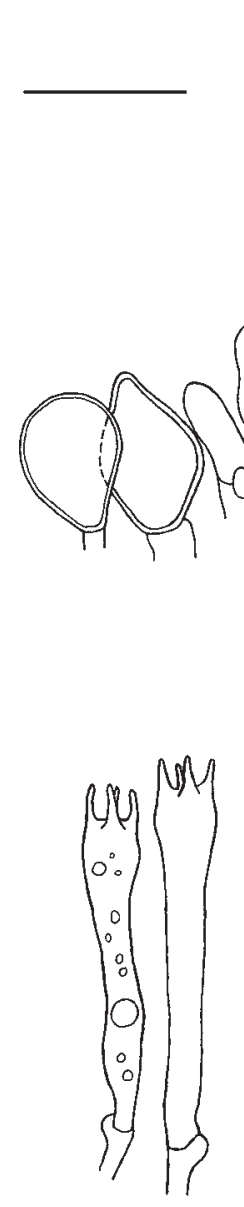

BA

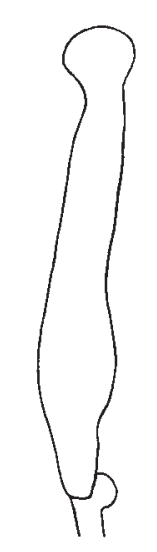

$\mathrm{HC} 1$

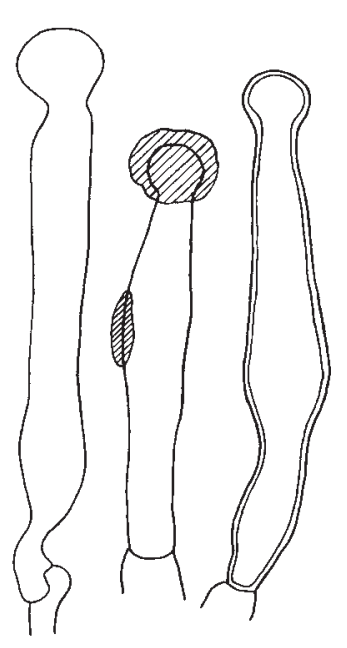

$\mathrm{PC}$

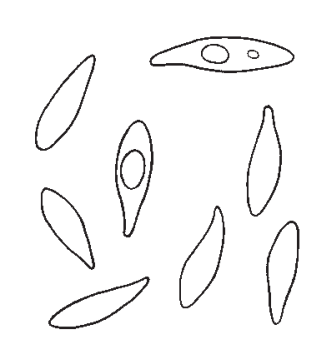

SP

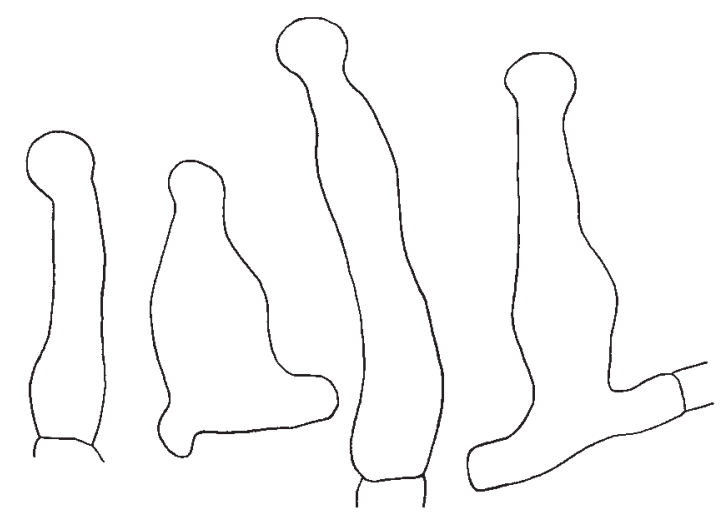

$\mathrm{CC}$

FIG. 2. Gloiocephala cerkezii. PP. Pileipellis. PC. Pileocystidia. BA. Basidia. HC1. Hymenial cystidia type 1. HC2. Hymenial cystidia type 2. SP. Spores. CC. Caulocystidia. All microscopic elements are drawn from the holotype, except for HC2 that is drawn from CNF 1/3482. Bar $=20 \mu \mathrm{m}$.

whitish to pale ochraceous, often with rusty brown dots or stains. Stipe (9-) 11-25 × 0.2-1 mm, central or slightly eccentric, cylindrical, often more or less broadened at the base, insititious to subinsititious, entirely pubescent, dry, usually whitish at apex (sometimes brown), downward brown, then black- brown to black (at least in the lower half). Context very thin. Odor absent. Flavor not observed. Spore-print white.

Spores (10.5-) 10.6-14.4-18.1(-21.0) × (3.1-)3.3$4.0-4.7(-5.2) \mu \mathrm{m}$, av. $12.8-16.4 \times 3.7-4.3 \mu \mathrm{m} ; \mathrm{SD}=$ $1.17-1.88-2.03 \times 0.21-0.36-0.46, \mathrm{Q}=2.4-3.6-5.3, \mathrm{Q}$ 
av. = 3.3-3.9, narrowly fusiform to narrowly clavate, hyaline, smooth, thin-walled, nonamyloid, nondextri-

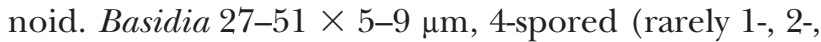
or 3-spored), narrowly clavate, hyaline, thin-walled, clamped. Basidioles narrowly clavate, less frequently subcylindrical, with an obtuse to moderately acute apex. Hymenial cystidia in two types: (i) one is similar to pileocystidia in size and shape, rare to almost absent (moderately abundant in only one collection); (ii) the other is hyphoid, subcylindrical to irregular, often with one or few short projections, hyaline, thinwalled, clamped, almost absent to moderately abundant, 23-50 × 2-5 $\mu \mathrm{m}$. Pileal and hymenophoral trama irregular, gelatinized, made up of $1-6 \mu \mathrm{m}$ wide, branched, often twisted and/or shrivelled, hyaline, thin-walled, clamped hyphae. Pileipellis hymeniform, made up of variously shaped elements, clavate, utriform, subglobose, ovoid, sphaeropedunculate, ellipsoid, conical, fusiform, subcylindrical, 10-43 $\times$ 3-24 $\mu \mathrm{m}$, apex sometimes more or less mucronate, hyaline, yellow-brown to dark rusty-brown, thin- to thick-walled $(<2[-3] \mu \mathrm{m})$, clamped, pigment parietal. Pileocystidia 37-85 $\times$ 5.5-13 $\mu \mathrm{m}$, apex 4.5-13 $\mu \mathrm{m}$, narrowly utriform, lageniform, fusiform, narrowly clavate or subcylindrical, almost always subcapitate to capitate, hyaline (more frequently) to yellow-brown, sometimes with yellow-brown to dark rusty-brown resinous exudates, mostly on apex, thin-walled, less frequently thick-walled $(<1.5 \mu \mathrm{m})$, abundant (rarely sparse), more frequent near margin of pileus, clamped. Stipitipellis a cutis, made up of $1.5-6 \mu \mathrm{m}$ wide, brown, thin- to slightly thick-walled $(<1 \mu \mathrm{m})$, clamped hyphae, with dark brown secreted clots, abundant in lower part of stipe, rare to abundant in upper part. Caulocystidia $21-75 \times 6-17 \mu \mathrm{m}$ (without broadened base), apex 4-10.5 $\mu \mathrm{m}$, subcylindrical, narrowly utriform, lageniform or fusiform, almost always with subcapitate apex, often with broadened base, hyaline to dark brown, sometimes with brown exudates, thin- to thick-walled $(<2.5 \mu \mathrm{m})$, abundant to sparse, clamped. Clamps abundant in all tissues, large.

Habitat. The species has been found in two different habitats. One is a small, wet, neglected grassland beside a forest road (forest with Quercus robur, Fraxinus angustifolia, Alnus glutinosa), on dead parts of Carex hirta near ground (often when those are still attached to a living plant). The other habitat is a neglected orchard with young but withering or dead trees of Prunus domestica, accompanied with Acer campestre, Cornus sanguinea, Corylus avellana, Juglans regia and Ligustrum vulgare, on dead root twigs of $P$. domestica on the ground level.

Phenology. (Jul)Aug-Sep(Oct).

Additional specimens examined. CROATIA: $38 \mathrm{~km}$ SE of Zagreb, $2.2 \mathrm{~km}$ WSW of the Dužica village, $45^{\circ} 31^{\prime} 54^{\prime \prime} \mathrm{N}$, $16^{\circ} 12^{\prime} 35^{\prime \prime} \mathrm{E}$, alt. $110 \mathrm{~m}$, wet grassland, on dead parts of Carex hirta, leg. M. Čerkez, 7 Sep 2002 (CNF 1/2754), 15 Sep 2002 (CNF 1/2765), 30 Aug 2003 (CNF 1/3095), 3 Oct 2003 (CNF 1/3149), 29 Aug 2004 (CNF 1/3482), 26 Aug 2006 $(1 / 4038)_{\lambda} 11 \mathrm{~km} \mathrm{NE}$ of Zagreb, Jalševec village, $45^{\circ} 52^{\prime} 08^{\prime \prime} \mathrm{N}$, $16^{\circ} 04^{\prime} 09^{\prime \prime} \mathrm{E}$, alt. $210 \mathrm{~m}$, neglected orchard, on dead root twigs of Prunus domestica, leg. M. Čerkez, 8 Sep 2002 (CNF 1/2761), 3 Jul 2003 (CNF 1/3081).

\section{DISCUSSION}

Gloiocephala cerkezii is characterized by its pale brown to rusty brown pileus, elongated central to slightly eccentric stipe, vein-like lamellae, large and elongate spores, subcapitate to capitate cystidia, a gelatinized trama, and the absence of hairs on the pileus and stipe. In Europe the species closest to G. cerkezii is $G$. menieri that differs by short ( $<2 \mathrm{~mm}$ long), lateral or strongly eccentric stipe, and wider spores (5.5$7.5 \mu \mathrm{m})$. Among extra-European species the closest are G. inobasis Singer, G. longisperma Singer and $G$. palmarum Singer (Singer 1976). G. inobasis differs by pure white pileus, spathuloid basidiocarps, longer and wider hymenial and pileal cystidia, and nongelatinized trama. G. longisperma differs by usually white, small pileus $(<3 \mathrm{~mm})$, lack of subcapitate and capitate cystidia, presence of hairs in pileipellis $(<200 \mu \mathrm{m})$, and regular, nongelatinized trama. $G$. palmarum differs by usually orange pigmentation in pileus, lateral to sublateral stipe, longer and wider pileocystidia, and nongelatinized trama. Gloiocephala cerkezii is easy to recognize macroscopically among all European agarics, so it is obviously an exceptionally rare species.

KEY TO ERUOPEAN SPECIES OF GENUS GLOIOCEPHALA This key is based on the literature descriptions (Bas 1961, Noordeloos 1981, 1987, 1995, Antonín and Noordeloos 1993, Bon 1999, Horak 2005), as well as on our collections.

1. Stipe (9-) 11-25 mm long, pileocystidia subcapitate to capitate..................... G. cerkezii

1. Stipe $<6(-10) \mathrm{mm}$ long, subcapitate to capitate pileocystidia absent, or when present, stipe $<2.5 \mathrm{~mm}$ long. . . 2

2. Lamellae vein-like and never reach the margin of the pileus; stipe stunted; pileus $<15 \mathrm{~mm}$ wide G. menier

2. Lamellae pretty well developed and at least some reach the margin of the pileus, or hymenium smooth to wrinkled; stipe well developed; pileus $<6 \mathrm{~mm}$ wide. . . . . . . . . . . . . . 3

3. Hymenium smooth to wrinkled; basidiocarps usually spathuloid.................... G. cornelii

3. Hymenium lamellate; basidiocarps never spathuloid 4

4. Basidia predominantly 2-spored; pileus white to whitish .............. G. caricis

4. Basidia 4-spored; pileus pinkish-ochraceous .... G. pseudocaricis (Noordel.) Tkalčec et Mešić, comb. nov. 
MYCOBANK MB 511241

Basionym: Marasmius pseudocaricis Noordel., Persoonia 11(3): 373, 1981.

\section{ACKNOWLEDGMENTS}

We are grateful for Mr Milan Čerkez's great fieldwork contribution to the knowledge of Croatian mycobiota, especially for the finding of this species. We also thank Prof D. Ivan Šugar for his help with the Latin description.

\section{LITERATURE CITED}

Antonín V. 2003. New species of marasmioid genera (Basidiomycetes, Tricholomataceae) from tropical Africa - II. Gloiocephala, Marasmius, Setulipes and two new combinations. Mycotaxon 88:53-78.

—, Noordeloos ME. 1993. A Monograph of Marasmius, Collybia and related genera in Europe. 1. Libri botanici 8. Eching b. München: IHW-Verlag \& Verlagbuchhandlung.

Bas S. 1961. The genus Gloiocephala Massee in Europe. Persoonia 2(1):77-89.

Binder M, Hibbett DS, Wang Z, Farnham WF. 2006. Evolutionary relationships of Mycaureola dilseae (Agaricales) a basidomycete pathogen of a subtidal rhodophyte. Am J Bot 93(4):547-556.

Bon M. 1999. Les collybio-marasmïoïdes et ressemblants. Flore Mycologique d'Europe 5. Documents Mycologiques Mémoire hors série 5. Lille: Association d'Ecologie et de Mycologie.

Corner EJH. 1996. The agaric genera Marasmius, Chaetocalathus, Crinipellis, Heimiomyces, Resupinatus, Xerula and Xerulina in Malesia. Nov Hedwig Beih 111:1-175.

Desjardin DE, Horak E. 1997. Marasmius and Gloiocephala in the South Pacific Region: New Guinea, New Caledonia and New Zealand Taxa. Bibl Mycol 168:1-152.

—_, Martínez-Peck L, Rajchenberg M. 1995. An unusual psychrophilic aquatic agaric from Argentina. Mycologia $87(4): 547-550$.

Horak E. 2005. Röhrlinge und Blätterpilze in Europa. München: Elsevier GmbH.

—, Desjardin DE. 1994. Reduced marasmioid and mycenoid agarics from Australasia. Aust Syst Bot 7:153170.

Manimohan P, Thomas KA. 1998. A new species of Gloiocephala from India. Mycotaxon 69:87-91.

Matheny PB, Curtis JM, Hofstetter V, Aime MC, Moncalvo JM, Ge Z-W, Yang Z-L, Slot JC, Ammirati JF, Baroni TJ,
Bougher NL, Hughes KW, Lodge DJ, Kerrigan RW, Seidl MT, Aanen DK, DeNitis M, Daniele GM, Desjardin DE, Kropp BR, Norvell LL, Parker A, Vellinga EC, Vilgalys R, Hibbett DS. 2007 " 2006". Major clades of Agaricales: a multilocus phylogenetic overview. Mycologia 98:982-995.

Mešić A, Tkalčec Z. 2002. Preliminary checklist of Agaricales from Croatia II: families Agaricaceae, Amanitaceae, Cortinariaceae and Hygrophoraceae. Mycotaxon 83: 453-502.

- -2003 . Preliminary checklist of Agaricales from Croatia IV: families Bolbitiaceae, Coprinaceae, Entolomataceae and Pluteaceae. Mycotaxon 87:283309.

Moncalvo J-M, Vilgalys R, Redhead SA, Johnson JE, James TY, Aime MC, Hofstetter V, Verduin SJW, Larsson E, Baroni TJ, Thorn RG, Jacobsson S, Clémençon H, Miller OK. 2002. One hundred seventeen clades of euagarics. Mol Phylog Evol 23:357-400.

Noordeloos ME. 1981. Notes on Marasmius-I. Marasmius pseudocaricis spec. nov. and the status of Gloiocephala Mass. Persoonia 11(3):373-376.

. 1987. Notulae ad floram agaricinam neerlandicamXV: Marasmius, Marasmiellus, Micromphale and Hohenbuehelia. Persoonia 13(3):237-262.

- 1995. Genus Marasmius. In: Bas C, Kuyper TW, Noordeloos ME, Vellinga EC, eds. Flora agaricina neerlandica 3. Rotterdam: A.A. Balkema. p 136153.

Singer R. 1960. Monographs of South American Basidiomycetes, especially those of the east slope of the Andes and Brazil 3. Reduced marasmioid genera in South America. Sydowia 14:258-280.

. 1976. Marasmieae (Basidiomycetes-Tricholomataceae). Flora Neotrop 17:1-347.

. 1986. The Agaricales in modern taxonomy. 4th ed. Koenigstein: Koeltz Scientific Books.

. 1989. New Taxa and new combinations of Agaricales (Diagnoses Fungorum Novorum Agaricalium IV). Fieldiana Bot 21:1-133.

Tkalčec Z, Mešić A. 2002. Preliminary checklist of Agaricales from Croatia I: families Pleurotaceae and Tricholomataceae. Mycotaxon 81:113-176.

- 2003a. Preliminary checklist of Agaricales from Croatia III: families Boletaceae, Gomphidiaceae and Paxillaceae. Mycotaxon 87:255-282.

- 2003b. Preliminary checklist of Agaricales from Croatia V: families Crepidotaceae, Russulaceae and Strophariaceae. Mycotaxon 88:279-314. 